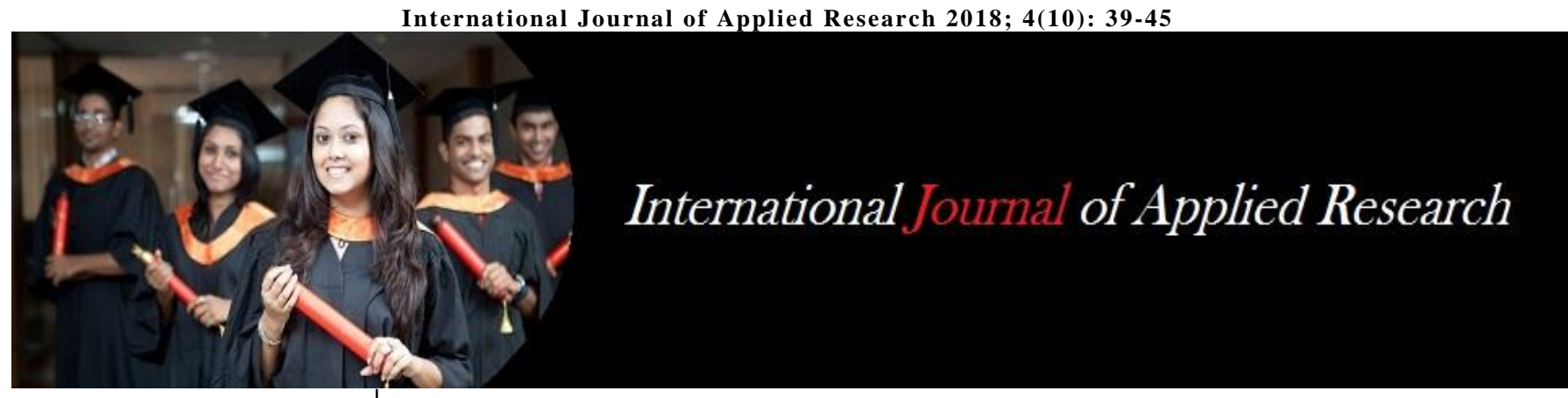

ISSN Print: 2394-7500 ISSN Online: 2394-5869 Impact Factor: 5.2 IJAR 2018; 4(10): 39-45 www.allresearchjournal.com Received: 10-08-2018 Accepted: 11-09-2018

Moses Jeremiah Barasa Kabeyi University of Nairobi,

Department of Mechanical and Manufacturing Engineering GPO, Nairobi, Kenya, East Africa
Correspondence

Moses Jeremiah Barasa Kabeyi University of Nairobi,

Department of Mechanical and Manufacturing Engineering GPO, Nairobi, Kenya, East Africa

\section{Michael porter's five competitive forces and generetic strategies, market segmentation strategy and case study of competition in global smartphone manufacturing industry}

\author{
Moses Jeremiah Barasa Kabeyi
}

\begin{abstract}
As per Porters five competitive strategies, to sustainably operate profitably, it is necessary for organizations to strategically deal with competition from both direct and indirect competitors who can affect the organization like influential customers, influential suppliers, new entrants, and substitute products. Market segmentation has proved to be an effective strategy in marketing of technology based products like smartphones. It was observed that the smartphone industry has a few players in manufacturing and with heavy capital costs limiting entry. The market is characterized by plenty of innovation through research and development which also increases the entry costs and harden exit for the players, the manufacturers are relatively few but competition can be said to be falling between intense and low. The suppliers have generally a lower bargaining power except for the software suppliers like google who have higher bargaining power. Smartphone manufacturers develop wide range of products targeting different market segments and in some cases phones with unique features are developed by various manufacturers as well as smartphones with different prices to suit different market segments. An analysis of the smartphone market shows that the market is approaching saturation in developed countries which also provide market for most of the smartphone sales but the developing countries like India and China have huge and fast market growth rates making the smartphone market growth to remain high globally. A combination of these factors and competitive forces show that the smartphone market is of moderate rivalry intensity and manufacturers can use a combination of different strategies to remain competitive. Market segmentation can facilitate implementation of the Porters generic strategies by smartphone manufacturers.
\end{abstract}

Keywords: completive forces, rivalry intensity, rivalry strategy tool, smartphones, generic strategies, market segmentation, competitive advantage

\section{Introduction}

The Five Competitive forces and Generic Strategies

\subsection{Porters Five Competitive Forces}

According to Porter (2008) ${ }^{[14]}$, an organization must strategically respond to competition and constantly monitor direct competitors and indirect competitors or potential competitors to avoid market ambush from unknown and unexpected market entrants and substitute products which can threaten your position and share in the competitive market. Other competitive forces in the market that can hurt an organization are customers who can force the organization to reduce prices by colliding the rivals, suppliers who may eat into your profits by charging higher prices for the raw materials and other inputs, aspiring or new entrants who may be equipped with even better abilities and are keen to gain entry and share the market, and substitute offerings who may lure your customers to their products and services at the expense of your products and services. New entrants often cap or limit growth in profits of an existing organization and should therefore be monitored and controlled.

Porter (2008) [14] advises companies to develop strategies that guarantee sustained profitability. These strategies include;

1. Concentrate operations where the competitive forces are weakest to your advantage for example if competitors target largescale customers for their products, then position yourself for small customers and if competitors are 
Targeting your local market then target the export market which in these cases are areas of weakness.

2. Take advantage of market changes or shifts of competitive forces in the market by identifying vacuums that are generated as a result of these changes. As an example, Apple took advantage of the need to sell music through a platform by a competitor to develop an IPod music player which became a market success.

3. Manipulate the competitive forces to your advantage using various strategies. For example dilute the power of suppliers through harmonization or standardization of specifications which makes it easier to change suppliers at will, counter customer power by expanding your services and diversification and control competitor initiated price wars by developing unique products. As for the threat of new entrants, scare them away by increasing entry costs and requirements through research and development as well as widening or increasing product access by the customers

\subsection{Michael Porters Five Generic Strategies}

According to Porter (2008) [14] and David (2011) [2], different strategies allow organizations to gain competitive advantage from three different bases namely:

\section{Cost leadership Strategy}

This emphasizes production of standard products at a low per-unit cost or consumers who are price-sensitive. Two alternative types of cost leadership strategies can be defined. Type 1 which is a low-cost strategy that offers products or services to a wide range of customers at the lowest price available on the market. Type 2 is a best-value strategy that offers products or services to a wide range of customers at the best price-value available on the market; the best-value strategy aims to offer customers a range of products or services at the lowest price available compared to a rival's products with similar attributes. Low cost and best value strategies target a large market (David, 2011) ${ }^{[2]}$.

\section{Differentiation Strategy}

This is Porter's Type 3 generic strategy, a strategy aimed at producing products and services considered unique in the market and directed at consumers who are relatively priceinsensitive. Best differentiation concentrates on products and services that are hard or expensive for rivals to imitate since competitors are continually trying to copy or benchmark, duplicate, so as to outperform others (David, 2011) ${ }^{[2]}$.

\section{Focus Strategy}

Focus involves producing products and services that fulfill the needs of small groups of consumers in a target market. Two alternative types of focus strategies are low-cost focus strategy that offers products or services to a small range of customers called niche group of customers at low price possible in the market. Best-value focus strategy offers products or services to a small range of customers at the best price-value available on the market. It is also called focused differentiation. It seeks to offer products or services that meet their preferences better than what rivals offer. The difference between the two focus strategies is that low-cost focus offers products or services at the lowest price, whereas Best-value focus strategy offers products/services at higher prices with more features hence the offerings are perceived as the best value.

In line with porter competitive forces larger firms would typically compete on a cost leadership and/or differentiation basis, but smaller firms would rather compete on a focus basis. If the market is large, it is difficult to pursue a focus strategy due to need for economies of scale needed for a low-cost or best-value cost leadership's strategy for competitive advantage (David, 2011) ${ }^{[2]}$.

\section{Market Segmentation Strategy for Competitive Advantage}

A market segment refers to a group or subgroup of people, organization with common characteristics that enable them to have identical products and service needs. A consumer market can be segmented based on demographic, geographic, product life cycle, product or service use rate and benefits characteristics or any other identifiable consumer characteristics (Neil, nd). Therefore market segmentation refers to subdividing a market along some commonality, similarity, or kinship so that members in a given segment share something in common (Thomas, 2017) [19].

Segmentation is based upon development demand side and involves adjustment of product and marketing effort to consumer or user the user requirements. Segmentation involves substantial use of advertisement and sales promotion and is essentially a merchandising strategy (Smith, 1995) [20]. Hunt and Arnett (2014) [9] view segmentation as one of the most widely acceptable marketing concept and strategy but warn that segmentation should be grounded in competition theory.

\subsection{Target Market Strategies}

Strategies that can be applied in market segmentation include;

1. Aggregation strategy where a seller treats a total market as a single market e.g. gasoline market or smartphone market.

2. Single segment strategy also known as concentration strategy where focus is on one segment of a total market e.g. Chinese smartphone market, African smartphone market, etc.

3. Multiple segment strategy where the organization targets more different groups of potential customers.

\subsection{Positioning for market segmentation}

In market segmentation, an organization should decide how best to position itself in relation to competitors for identified market segment. This positioning could be based on price, product design features, distribution method used or unique selling options developed for a given product or service, product lifecycle, and consumers lifestyle.

\subsection{Repositioning in market segmentation}

This is a strategy used when changing consumer perception of a brand against competitor offerings. Repositioning is done to sustain in slow growth market or to correct errors/mistakes committed during the positioning phase (Hunt and Arnett, 2014) ${ }^{[9]}$ 


\subsection{Importance of Correctly Identifying and Choosing a Firm's Markets}

Slater, Hult, \& Olson (2007) ${ }^{[18]}$ noted that business strategy is refers to a set of activities required to create better customer value in the markets with the objective of achieving superior or unique performance. The two strategies or marketing activities required to achieve this objective are:

1. The adoption of the best or most appropriate strategic orientation or behaviors e.g. competitor orientation, technology orientation and customer orientation

2. Targeting of the right market and market segments which could be the innovators, early adopters, early majority, late majority or the laggards

According to Walker \& Ruekert (1987) ${ }^{[21]}$ marketers in prospector firms need to be aware of the firms technical capacity when engaging the market while R\&D should be customer-oriented when creating new products as well as developing important technologies. They observed that prospectors may not even recognize who their competitors or potential competitors are, instead they are focused on the market and customers. So, prospectors should demonstrate more concern with their target customers and the technology that delivers products to markets than with competitors. Slater, Hult, and Olson (2007) ${ }^{[18]}$ noted that Prospectors are the most proactive and innovative of the strategy types. They noted that exploration for new opportunities is a central theme in innovation and that exploration may take the form of "outside-in" processes, that is customer-oriented behaviors, or of "inside-out" processes, which is purely R\&D driven innovation. According to Walker \& Ruekert (1987) ${ }^{[21]}$ and Miles \& Snow (1978) ${ }^{[12]}$ prospector business units take an aggressive new product-market position and are often industry pioneers in the creation and development of new technologies, products, and services in the market. As a result of this, they may have little or no reference to competitors or business rivals, but are rather concerned with the customers and the target market.

The early market for innovative products are both innovators and early adopters with innovators being buyers who appreciate innovation for its own sake and are motivated by the idea of being change agents. Therefore to be successful, prospectors should target innovators and adopters not just the entire market. On the other hand early adopters want to use innovation to achieve some revolutionary improvements. They are attracted by highrisk, high-reward projects, and because they envision great gains they are not quite price sensitive. Customers in the early market typically demand personalized solutions and quick-response, highly qualified sales and support services (Slater, Hult, \& Olson, 2007) ${ }^{[18] .}$

Gatignon and Xuereb (1997) [6] noted that customer orientation significantly improves product performance in the market but only in markets where the demand uncertainty is high. They however noted that market orientation detracts from performance when demand uncertainty is low. In their study on prospector analysis and performance Slater, Hult, and Olson (2007) ${ }^{[18]}$ found out that there is no relationship between customer orientation and performance and that there is a negative relationship between targeting the early majority and performance of the product in the market.

\section{Rivalry Intensity: High and low Intensity}

According to Harrison, Hitt, Hoskisson \& Ireland (2008) ${ }^{[8]}$ and Wilkinson (2013) ${ }^{[22]}$, the intensity of rivalry among industry competitors is the extent to which firms put pressure on one another and limit each other's performance in an industry. As a result, this reduces profit potential for all firms within the industry. Intensity of rivalry among firms shapes the competitive structure of an industry according to Porter's five forces framework and influences the ability of existing firms to achieve profitability. High intensity makes an industry more competitive while low intensity of competitive rivalry makes an industry less competitive and increases the firms 'profit potential.

\subsection{High Intensity of Rivalry in an Industry}

Harrison, Hitt, Hoskisson \& Ireland (2008) ${ }^{[8]}$ and Wilkinson (2013) ${ }^{[22]}$ identified the following Characteristics of high intensity rivalry;

1. Significant number of competitors in the market competing for common customers and markets.

2. Rate of growth of the industry is low and sellers and manufacturers struggle over same customers.

3. The industry requires high fixed costs hence huge capital requirements to enter the market.

4. Competing firms tend to have equal capacities in terms of size and ability to outdo each other.

5. The level of product differentiation tend to be limited hence customers have limited choices of product and sellers.

6. Customers have limited brand loyalty hence keep switching freely between different products and competitors.

7. Customers have low switching costs so change to a competitor is much easier and almost flawless

8. The rivals have same market share and influence and hence equal chances to win over customers from rivals and vice versa.

9. Different strategies are employed by the competitors to outdo one another in the market

10. Underutilization of production capacity by the competing organizations.

11. There many industry exit barriers forcing players to stay put and struggle for survival and space in the market

\subsection{Low Intensity of Rivalry}

Hitt, Hoskisson \& Ireland (2008) ${ }^{[8]}$ and Wilkinson (2013) ${ }^{[22]}$, identified the following characteristics of low intensity rivalry in the market. :

1. The number of competitors in the market is low

2. The few competitors have different sizes and abilities

3. The business rivals have different size of market share or control hence different influence and control over the markets.

4. The rate of growth of the Industry is higher hence more and more customers and markets keep presenting themselves meaning more opportunities.

5. Entry costs for the industry are low hence unrestrictive giving room for new entrants

6. Wide range of products through differentiation. This provides room for more new markets and strategies enabling competitors to pursue different strategies and markets. 
7. Customer's loyalty to brands is high since choice is limited and so they have to cope with limited options.

8. Switching costs by customers are restive or high meaning that it becomes prohibitive to change suppliers or sellers thus customer retention is higher.

9. Competitors are not strategically diversified hence apply similar strategies

10. Production capacity is fully utilized as the market is ready to absorb production

11. Limited exit barriers from the industry by sellers or manufacturer hence investors do not have to struggle so much to keep the business going just like it is easier to enter the market.

Low intensity of rivalry by competitors makes an industry more attractive while increasing profitability for the competing firms (Wilkinson, 2013) ${ }^{[22]}$.

\section{Analysis of the Influence of Market Selection in Business Strategy Development}

Market selection is an important step important step to successfully launch a product in a given market. Important considerations in market selection are market size, growth rates, analysis of competitive forces, new product developments, population factors and operating business environment, economic factors and consumer-related factors that influence market potential. Market strategies like exporting and licensing need less investment, but leads to least control of the business while joint venture and $100 \%$ ownership have more managerial requirements and capital but enhances control over operations of the organization so it is better to employ different strategies for different markets. The nature and type of the products and services should also be considered because of significant need for after-sales service, or significant amount of contacts with the customer will require direct ownership and control. (Boumphrey, 2016) ${ }^{[1]}$.

\section{Overview of Global Smartphone Industry \\ 4.1. Introduction}

A smartphone a handheld personal computer which has extensive computing capabilities, with access to the Internet using both Wi-Fi and mobile broadband. Most smartphones also are built with support for Bluetooth and satellite navigation with modern smartphones having touchscreen color display. Smartphones use a mobile operating system, and are able to process a variety of software components, known as apps (Reisinger, 2017) ${ }^{[16]}$.

\subsection{Market Analysis and Potential}

The smartphone industry is one of the fastest growing and dynamic industry mainly due to growing need of internet services, availability of cheap and affordable phone combined with growing internet connectivity around the world. A smartphone is a mobile phone that functions like a computer. It typically has a touchscreen interface, Internet access, and an operating system that can run application software or apps that are integrated with other devices and sensors to provide users information on a real-time basis. The phone can be can be used in a number of applications, including making calls, instant messaging, taking pictures and videos, browsing the Internet, carrying out financial transactions, creating presentations, and analyzing data. Almost 10 years ago, performing these functions without a computer were considered impossible. Key venders are
Apple, Samsung, Huawei, OPPO, Vivo, Xiaomi, Lenovo, LG Electronics, Sony, and ZTE. Other players are ASUSTeK Computer, google, BlackBerry, Gionee Communication Equipment, Micromax, Microsoft, OnePlus, Nokia and Panasonic with the Market driver being rising income levels and increasing consumer spending in emerging markets. As far as the smartphone market is concerned, the main challenge experienced is that developed countries where most of the market exists are reaching market saturation while the market trend today is upcoming possibilities or innovations include with 5G network (Global Information, Inc., 2018) ${ }^{[7]}$.

As for future potential of smartphone industry presents, developing economies like India are quite have huge potential with an emerging middle-class population of more than 500 million and about $65 \%$ of the population aged 35 and below in India. This population benefit, with an increasing smartphone user base of about 340 million, improved data and internet access and affordability, and expanding electronic payment ecosystem supported ambitious Digital India project, is giving fresh impetus to the adoption of e-commerce across the country. India, which is a growing economy and the second largest smartphone market in the world, is prove of huge growth potential for the smartphone industry around the world.

\subsection{Intensity of Rivalry within the Smartphone Manufacturing Industry}

This refers to the level of completion between competitors and rivals through advertisements, product quality, price wars, differentiation and other strategies (Johnson, 2014) [10]. Customers are less willing to switch the operating system they are used to while Suppliers such as operating system providers have moderate power in the industry. Inputs for the high-end markets are quite specialized hence suppliers have more bargaining power but not at the low end. Rivalry in the smart phone industry is moderate, because customers tend to have high brand loyalty at the high end of the market. The market does not have many potential substitute of smartphones, but PCs and Tablets can be considered as substitute but not really, thus force of substitutes is moderate low in smartphone industry (Zhuo, 2017) ${ }^{[23]}$. The industry has huge customer base of over 968 Million worldwide. The Industry is growing at rate of 28$30 \%$ worldwide and at $168.8 \%$ in India. Top players in smartphone market include Samsung, Apple, Huawei, Lenovo, Xiomi and LG. Samsung is dominant player in the smartphone market with nearly $25 \%$ market share in the second quarter of 2014. This share has come down from $32.2 \%$ from a year before. Apple has lost $2 \%$ from previous year to settle down at $11 \%$ in the second quarter of 2014. On the other hand Xiomi emerged as a new player in the smartphone market which has seen increase in market share from $1.8 \%$ to $5.10 \%$ in just one year (Sushtend Nexus, 2016) [17]. Analysis shows drops in market share by Samsung and Apple, fewer players with each having different market share, significant product differentiation and a huge growing market especially in India and globally, the rivalry in smartphone industry can be said to be nether low nor high, hence moderate.

However according to Djajadikerta (2017) ${ }^{[4]}$, rivalry in smartphone industry is stiff with the target being standard phone features like the software's used and security, cameras, screens, touchscreen quality. These feature are 
relatively easy to imitate and even produce better products to get competitive advantage.

\subsection{Intensity of Supplier Power in Smartphone Industry}

This refers to the bargaining power of suppliers which is their ability to exert pressure and influence competitors to increase their prices leading to their profitability and other benefits at the expense to the supplier's profitability and even competitiveness (Johnson, 2014) ${ }^{[10]}$. Pratap (2017) ${ }^{[13]}$ on suppliers and their power in the smartphone industry observed that Apple has managed a complex chain of suppliers that are spread globally over several nations including United States, China, Japan, Mexico, Brazil and other countries This huge number of limits their bargaining power with Apple. Apple also maintains excellent control over its suppliers. Switching costs are low for Apple but for suppliers, they would not like losing their business with Apple. At the same time there is no potential of forward integration by the suppliers. Therefore Apples position against its suppliers is strong and while their bargaining power weak. Nokkia on its side relies on its suppliers to supply equipment for their advanced mobile phones and a large number of equipment makers are involved and so which Nokia could switch to.

However the software suppliers for their Smartphones are now Microsoft, who has a high bargaining power. As the leading company in the industry, Nokkia is in a stronger position when bargaining with other suppliers. As a conclusion, there is a moderate threat from the powers of suppliers for Nokkia because although the hardware suppliers have a very low power, Microsoft's power over the software is very high because they're very few other organizations who have the expertise and skills to rival Microsoft.

As for Samsung the bargaining power of suppliers working with Samsung depends on the specific type of supplier. Samsung has about 579 suppliers globally and the company's supply chain includes over 2,700 suppliers in various industries around the world. General parts and components suppliers do not have substantial bargaining power due to the importance of Samsung's order volume and its ability to negotiate prices with suppliers. On the other hand, Google exercises significant bargaining power as the supplier of Android platform due to the lack of alternative platforms available to Samsung. Therefore smartphone manufacturers have a stronger power over suppliers for most parts but the software's used with Google and Microsoft having an upper hand (Pratap, 2017) ${ }^{[13]}$.

This shows that not all suppliers for smartphone manufacturers have the same influence with software suppliers having more power over the manufacturers compared to parts manufacturers.

\subsection{Threat of Substitutes}

Threat of substitutes refers to the level to which products and services can be exchanged with other products and services in the competitive market (Johnson, 2014) ${ }^{[10]}$. Smartphones can be substituted by tablets in the market which have similarities in terms of device interface, apps and functionality. However, smartphones may prove quite attractive to more customers because with similar capabilities, they come in unique shapes, sizes and functionalities (Djajadikerta, 2017) ${ }^{[4]}$.

\subsection{Threat of New Entrants}

According to Porter (2008) ${ }^{[14]}$ new entrants influence the level of profitability and industry attractiveness and identifies six barriers to new entrants. The startup costs for new smartphone manufacturers are extremely high hence low threat by new entrants as this makes entry difficult. However few entrants continue to join the industry particularly those targeting low and middle class customers. For example MicroMax joined the industry in 2010 and become the tenth largest smartphone company in the world (Djajadikerta, 2017) ${ }^{[4]}$.

\subsection{Purchasing Power of Buyers}

Bargaining power of buyers refers to the ability of buyers to exert pressure or influence competitors in an industry leading to their profit reductions, better quality and better services at the expense of the competitors (Johnson, 2014) [10]. Smartphone manufacturers like Samsung and Blackberry need the customers who at the same time can easily be lured by the rivals products and prices. This ultimately grants smartphone customers moderate to high bargaining power over the smartphone manufactures. With low switching costs, their position bargaining power is further strengthened. The customer demand is elastic and highly price sensitive (Djajadikerta, 2017) ${ }^{[4]}$. Therefore to manage buyer power, smartphone manufacturers should develop affordable, diverse and easily accessible phones.

\subsection{Recommendations for Smartphone Manufacturers to Gain Competive Advantage}

For sustainable long-term profitability by smartphone manufacturers and guaranteed leadership, the companies should reshape the competitive forces to their advantage as follows;

1. Manage competitor initiated price wars by making smartphones that differ significantly from competitor's offerings. This will ensure that the products are unique and this way give the manufacturer a competitive advantage.

2. Discourage new entrants by increasing capital requirements for investments and this can be realized heavy investment in innovation, research and development. Heavy investments and maintenance in distribution channels will also deter new entrants from market entry or displacing incumbent's manufacturers from the shelves. Price wars can also keep off new entrants when incumbents decide to utilize their economies of scale. Incumbents should also have sufficient war chest in terms of excess capacity, excess cash reserves and unutilized borrowing power and making switching costs high. Smartphone manufacturers and sellers should develop strong distribution networks by investing in them and also invest in research and development. This will significantly increase the entry requirements and limit or discourage new entrants (David, 2011) ${ }^{[2]}$.

3. To contain customer power smartphone manufacturers should expand their product range and service to make it difficult to leave for a different manufacturers or products. Retaining customers through will significantly reduce their bargaining power at the advantage of the smartphone manufacturers.

4. To neutralize supplier power standardize product specifications so that parts it becomes easier for the 
smartphone manufacturer to switch among vendors when necessary. Also make use of several suppliers around the world and not just relying on a few localized vendors at the next door. If suppliers seek huge profits smartphone manufacturers can credibly threaten to integrate backward and produce the industry's product themselves if vendors become too much profit seeking. In such like cases, investing or threatening to invest in own supplies can help tame or neutralize the suppliers and their power or influence (Dyer, Godfrey, Jensen, \& Bryce, 2016) ${ }^{[5]}$.

5. Manage the threat of substitutes by offering phones with better value, easier access to the markets and customers, value added products and services with increased product functionalities and quality at affordable or reasonable prices. Through alliances and cooperation with authorities, substitute smartphones in the name of generics and copy cats should be legally controlled. Manufacturers should avoid scenarios where substitutes offer attractive price-performance tradeoff to smartphones.

6. Apply market segmentation as a competitive strategy to facilitate implementation of Porters generic strategies like differentiation and focus.

\section{Conclusion}

Porter's five competitive forces and generic strategies continue to be effective and relevant to completive markets like fast growing smartphone industry. Analysis of the smartphone industry shows an industry with plenty of innovation through research and development which also increases the entry costs and harden exit for the players. The industry has relatively fewer manufacturers but competition can be said to be falling between intense and low. The suppliers have generally a lower bargaining power except for the software suppliers like google. Manufacturers develop wide range of products targeting different market segments and in some cases phones with unique features are developed by various manufacturers. An analysis of the smartphone market shows that the market is approaching saturation in developed countries which also provide market for most of the smartphone sales but the developing countries like India and China have huge and fast growing markets. This makes the smartphone market growth remain high. A combination of these factors and competitive forces show that the smartphone market is of moderate intensity. With product differentiation and diversification, market segmentation for smartphone manufacturers can be an effective marketing strategy for competive advantage.

\section{References}

1. Boumphrey S. How to perfect your market entry strategy. Euromonitor International. 2016. Retrieved from

https://blog.euromonitor.com/2016/12/perfect-marketentry-strategy.html

2. David FR. Strategic management concepts and cases. Upper Saddle River, New Jersey: Prentice, 2011.

3. Dedrick J, Kraemer KL. Economic Research Working, Intangible assets and value capture in global value chains: the smartphone industry, 2017, 41. Retrieved from

http://www.wipo.int/edocs/pubdocs/en/wipo_pub_econ stat_wp_41.pdf
4. Djajadikerta NF. Will implementing android operating system into Blackberry Limited's products provide them with the much needed support to improve their financial situation? The International Journal of Business \& Management. 2017; 5(5):127-132. Retrieved from www.theijbm.com/force_download.php?file_path=wpcontent/uploads/...pdf

5. Dyer JH, Godfrey P, Jensen R, Bryce D. Strategic management: Concepts and tools for creating real world strategy. Hoboken, NJ: John Wiley \& Sons, 2016.

6. Gatignon H, Xuereb J-M. Strategic orientation of the firm and new product performance. Journal of Marketing Research. 1997; 34(1):77-90. Retrieved from https://flora.insead.edu/fichiersti_wp/Inseadwp1995/9542.pdf

7. Global Information Inc. Global Smartphone Market, 2018, 2017-2021.

https://www.giiresearch.com/report/infi323567-globalsmartphone-market.html

8. Harrison JS, Hitt MA, Hoskisson RER, Ireland D. Competing for advantage. United States: Thomson South-Western, 2008. Retrieved from

https://www.researchgate.net/publication/235476076_C ompeting_for_Advantage

9. Hunt SD, Arnett DB. Market Segmentation Strategy, Competitive Advantage, and Public Policy: Grounding Segmentation Strategy in Resource-Advantage Theory.

10. Australasian Marketing Journal. 2004; 12(1):7-12. Retrieved from

https://www.sciencedirect.com/science/article/abs/pii/S 144135820470083X

11. Johnson MLSL. The 5 Competitive Forces Framework in a technology mediated environment. Do these forces still hold in the industry of the $21^{\text {st }}$ century, 2014.

Retrieved from https://essay.utwente.nl/66196/1/Johnson_BA_MB.pdf

12. Neil Armstrong N. (N.D.). Market research \& developing a marketing plan. Retrieved from http://www.regionalbusiness.ca/images/pdfs/market_res earch_guide.pdf

13. Miles RE, Snow CC. Organizational Strategy, Structure and Process. Academy of Management. 1978; 3(3):546564. Retrieved from https://www.jstor.org/stable/pdf/257544.pdf?refreqid=e xcelsior $\%$

14. Pratap A. Porter's Five Forces Analysis of Apple Inc. cheshnotes, 2017. Retrieved from https://www.cheshnotes.com/2017/02/porters-fiveforces-analysis-of-apple-inc/

15. Porter ME. The five competitive forces that shape strategy. Harvard Business Review. 2008; 86(1):78-93. Retrieved from

https://cb.hbsp.harvard.edu/cbmp/p1/71270434/7127043 8/fc8e5ea411

16. PWC. Balancing superior customer experience and data protection: The next challenge for Indian e-commerce. Tech World. 2018. Retrieved from https://www.pwc.in/assets/pdfs/industries/technology/te chworld-may-2018.pdf

17. Reisinger D. Worldwide smartphone user base hits 1 billion [Weblog]. 2017. Retrieved from https://www.cnet.com/news/worldwide-smartphoneuser-base-hits-1-billion/ 
18. Sushtend Nexus. Porter's 5-force analysis of the smartphone industry. 2016. [Web blog]. Retrieved from http://sushtend.blogspot.com/2016/02/porters-5-forceanalysis-of- smartphone.html

19. Slater SF, Hult GT, Olson EM. On the importance of matching strategic behavior and target market selection to business strategy in high-tech markets. Journal of the Academy of Marketing Science. 2007; 35:5-17. doi 10.1007/s11747-006-0002-4

20. Thomas JW. Market Segmentation. Decision Analyst. 2017. Retrieved from https://www.decisionanalyst.com/media/downloads/Ma rketSegmentation.pdf

21. Smith WR. Product differentiation and market segmentation as alternative marketing strategies. Market Management. 1995; 4(3):63-65. Retrieved from https://pdfs.semanticscholar.org/2664/435c9eb4169c9e 6afffa8bd0d08684d853d3.pdf

22. Walker OC, Ruekert RW. Marketing's role in the implementation of business strategies: A critical review and conceptual framework. Journal of Marketing. 1987; 51(3):15-33. Retrieved from https://www.jstor.org/stable/pdf/1251645.pdf?refreqid= excelsior

23. Wilkinson J. Intensity of Rivalry (one of Porter's Five Forces). 2013. Retrieved from https://strategiccfo.com/intensity-of-rivalry-one-ofporters-five-forces/

24. Zhuo K. Porter's Five Forces Analysis-The Smartphone Industry. 2017.

https://medium.com/@keyue.zhuo.14/entry-moderate442f5a0b304b 